\title{
Performance and Economic Prospect of Pigeonpea Varieties in Pigeonpea-Maize Strip Intercropping in Limpopo Province
}

\author{
Joseph Nwafor Akanwe Asiwe* and Koketso Sherleen Madimabe \\ University of Limpopo, Private Bag X 1106 Sovenga 0727, South Africa \\ *For correspondence: joseph.asiwe@ul.ac.za \\ Received 18 March 2020; Accepted 10 June 2020; Published 10 December 2020
}

\begin{abstract}
Pigeonpea is an important grain legume, and is traditionally intercropped with maize in West Africa and India. Small farmers in Limpopo Province, South Africa, who cultivate pigeonpea landraces under traditional mixed intercropping, experience the challenge of low productivity. Strip intercropping is a novel cropping system has greater efficiency and productivity in resource utilization when compared to mixed intercropping. Therefore, this study was conducted to evaluate the performance of improved pigeonpea varieties under a pigeonpea-maize strip intercropping system. Five pigeonpea varieties (ICEAP 001284, ICEAP 00604, ICEAP 87091, ICEAP 00661 and ICEAP 01101-2) were intercropped in maize as mixed and strip intercropping during the 2015-2016 and 2016/2017 cropping seasons while monocrops of both crops were also maintained as control. The trial for each season was replicated three times in a split plot design. During both seasons, ICEAP 001284 and ICEAP 00604 exhibited the shortest number of days to attain 50\% flowering under strip intercropping and monocropping when compared to the remaining varieties. Higher significant $(P<0.05)$ grain yields $\left(1726 \mathrm{~kg} \mathrm{ha}^{-1}, 1478 \mathrm{~kg} \mathrm{ha}^{-1}\right.$ and $858 \mathrm{~kg}$ $\mathrm{ha}^{-1}$ were obtained under strip intercropping for ICEAP 001284, ICEAP 01101-2 and ICEAP 00604, respectively during 2016/2017 than their respective grain yields during 2015/2016 season. Strip intercropping out-performed mixed intercropping with a higher land equivalent ratio and cash returns due to its ripple effect in the enhanced yield components. Among the five pigeonpea varieties, ICEAP 001284, ICEAP 00604 and ICEAP 01101-2, performed exceedingly well in their crop mixtures. In conclusion, the three pigeonpea varieties were selected for cultivation under strip intercropping. Strip intercropping exhibited greater efficiency in resource utilization and productivity over mixed intercropping in terms of grain yield, land equivalent ratio, net profit, and benefit-cost ratio. (C) 2021 Friends Science Publishers
\end{abstract}

Keywords: Cajanus cajan; Cropping system; Economic analysis; Maturity; Grain yield; Land equivalent ratio

\section{Introduction}

Pigeonpea (Cajanus cajan) is one of the important grain legume crops grown in the tropics and subtropics. It is believed to have originated from India (Saxena et al. 2002). It is a multi- purpose drought-tolerant crop, producing seeds for human consumption as a cheap source of protein (Loboguerrero et al. 2019). It contains 18-25\% protein, 51$58 \%$ carbohydrate, and important minerals and vitamins. It also provides good quality fodder for animal feed (Gwata 2010). Beside the nutritional value of pigeonpea, it is an important source of earning family income by farmers and others in the value chain such as processors, wholesalers and retail marketers as well transporters (Ayenan et al. 2017). Cultivation of pigeonpea also helps to improve the soil fertility through biological nitrogen fixation (Sharma et al. 2010; Carranca et al. 2015; Fossou et al. 2016). Pigeonpea can fix up to $235 \mathrm{~kg} \mathrm{~N} \mathrm{ha}^{-1}$ and produces more $\mathrm{N}_{2}$ per unit area from plant biomass than many other legumes (Njira et al. 2012).
Maize (Zea mays L.) is the third most important cereal crop in the world after wheat (Triticum aestivum L.) and rice (Oryza sativa L.). Maize grain is used for many purposes; for instance, as a staple food for human beings; feed for livestock; and as a raw material for many industrial products (Shah et al. 2016; Mango et al. 2018). In Limpopo Province, smallholder farmers cultivate landraces of pigeonpea, which are characterized by late maturity, and low grain yield due to their sensitivity to photoperiod (Asiwe et al. 2011; Gwata and Shimelis 2013). Farmers plant the landraces without definite row arrangement such as mixed intercropping. This practice does not optimise plant density or allow for an efficient utilization of resources. Intercropping of legumes with cereals is an ancient practice and is important for the development of sustainable food production systems, particularly among small holder farmers in South Africa (Kiwia et al. 2019).

Cereal-legume intercropping is commonly practised in South Africa, including the Limpopo Province, because of its yield advantage, greater stability and lower risks to crop 
Improving Pigeonpea-maize Productivity through Strip Intercropping/ Intl J Agric Biol, Vol 25, No 1, 2021

failure that are often associated with monoculture (Kermah et al. 2017). Intercropping cereals with grain legumes has often recorded an overall systems advantage compared with sole cropping of each crop (Zhang et al. 2015). Different researchers have reported cereal-legume intercrop trials in South Africa and elsewhere. These include maize and pigeonpea (Mathews et al. 2001; Nassary et al. 2020), and maize and dry bean intercropping (Kutu and Asiwe 2010), and wheat-canola (Bracica juncea L.) intercropping (Khan et al. 2012).

Strip intercropping refers to the growing of two or more crops together in strips wide enough to permit the separate management of crops, but close enough for the crops to interact agronomically (Singh and Ajeigbe 2007). Strip intercropping has the potential of reducing interspecies competition, and increasing yields per unit area. However, little or no research has been conducted in the assessment of the performance of improved pigeonpea varieties under strip intercropping in Limpopo Province. Therefore, there is a dire need to conduct field trials on a pigeonpea-maize strip intercropping system in Limpopo Province. This study aimed to evaluate the performance of five improved pigeonpea varieties under a pigeonpea-maize strip intercropping system in Limpopo Province, South Africa. The important benefits of the study were to give farmers the opportunity of selecting promising varieties for adoption and to observe the efficiency and comparative yield advantage of strip intercropping over their traditional method of mixed intercropping.

\section{Materials and Methods}

\section{Description of the study area}

The experiment was conducted at the University of Limpopo Experimental Farm (UL Farm, Mankweng, 235' 9.6 S, 2943' 4. 8' E) during the 2015/2016 and 2016/2017 seasons. The soil at the UL Farm is sandy loam in texture and belongs to Hutton form. Mean average summer day temperature varies between $28^{\circ} \mathrm{C}$ and $30^{\circ} \mathrm{C}$ while the area receives the mean annual rainfall ranging between 400 and $650 \mathrm{~mm}$.

Physio-chemical characteristics of the soil in the experimental site and weather conditions during the two seasons are given in Table 1 and 2.

\section{Experimental materials}

Five varieties of pigeonpea, namely, ICEAP 001284, ICEAP 00604, ICEAP 87091, ICEAP 00661, ICEAP 01101-2, and maize variety (PAN 6479, obtained from PANNAR Seed Ltd., South Africa) were planted in the field. The seeds of pigeonpea varieties were obtained from ICRISAT-Kenya, and were selected as an earlymedium range of maturity from previous pigeonpea evaluation trials.

\section{Treatments}

The trial was laid out in a split-plot design and replicated three times. The main plot factor was cropping system (intercrop and monocrop), the mono and mixed cropping were included as standard control practices. The subplot factor was the variety, which consisted of five pigeonpea varieties (ICEAP 001284, ICEAP 00604, ICEAP 87091, ICEAP 00661 and ICEAP 01101-2), and the trial was planted in three replications. The maize cultivar (PAN 6479) was planted in an inter-row spacing of $0.9 \mathrm{~m}$ and intra-row spacing of $0.3 \mathrm{~m}$ with a row length of $4 \mathrm{~m}$ giving a plant population of 52 and 32 plants per intercrop plot for maize and pigeonpea respectively, and each plot area was $5.6 \mathrm{~m} \times$ $4.0 \mathrm{~m}$. The intercrop plots consisted of four rows of pigeonpea sandwiched between two rows of maize. The monocrop plots consisted of six rows of pigeonpea and maize planted at an inter-row spacing of $0.75 \mathrm{~m} \times 0.5 \mathrm{~m}$ and $0.9 \mathrm{~m} \times 0.3 \mathrm{~m}$, respectively. The net plot for each intercrop was $4.8 \times 4.0 \mathrm{~m}$, while that for the monocrop (maize) was $4.8 \mathrm{~m} \times 4.0 \mathrm{~m}$ and $3.0 \mathrm{~m} \times 4.0 \mathrm{~m}$ for the pigeonpea monocrop.

\section{Crop management}

The experiment plot was prepared by using a tractor to plough and harrow, to ensure a good seed bed. The first season trial was planted on 13 January 2016 when rain was stable. The rainfall was stable earlier during the second season and the planting was done on 13 December 2016 (Table 2). Roundup (Isopropylamine salt of Glyphosate) and Dual (S-Metalachlor) at a rate of $3 \mathrm{~L} / \mathrm{ha}$ and $0.5 \mathrm{~L} / \mathrm{ha}$, respectively, were applied to control weeds at planting, and subsequently, two manual weeding cycles were carried out to control weeds during crop growth. Karate (LambdaCyhalothrin) was applied at the rate of $1 \mathrm{~L} / \mathrm{ha}$ to control insects on pigeonpea at the flowering stage until pod maturity. The study was conducted under rainfed and supplementary irrigation was only applied at planting to enhance seedling establishment. Basal application of NPK: 15:15:15 fertilizer of $50 \mathrm{~kg}$ per hectare was made at the time of planting.

\section{Data collection}

Pigeonpea: The number of days to $50 \%$ flowering was determined by counting the number of days from planting to the date that $50 \%$ of the plant population had flowered. It was rated by in-field visual observation. The number of days to $90 \%$ physiological maturity was determined by counting the number of days taken from planting to when $90 \%$ of the plant population had reached physiological maturity. Five plants were tagged randomly from the middle rows for sampling. The number of primary branches from the five tagged plants was counted and the mean number was calculated. 
Asiwe and Madimabe / Intl J Agric Biol, Vol 25, No 1, 2021

Table 1: Pre-sowing physio-chemical properties of the soil during 2015-2016 and 2016-2017 seasons

\begin{tabular}{|c|c|c|}
\hline \multirow[t]{2}{*}{ Soil composition } & \multicolumn{2}{|c|}{ Season } \\
\hline & 2015-2016 & $2016-2017$ \\
\hline Clay & 3 & 2 \\
\hline Silt & 13 & 14 \\
\hline Sand & 84 & 84 \\
\hline Textural class & Sandy loam & Sandy loam \\
\hline \multicolumn{3}{|l|}{ Chemical composition } \\
\hline $\mathrm{pH}$ in $\mathrm{H}_{2} \mathrm{O}(1: 2.5)$ & 7.4 & 8.2 \\
\hline Organic matter (\%) & 3.17 & 1.00 \\
\hline Available P (mg/kg) & 2.05 & 1.19 \\
\hline Ammonium N (mg/kg) & 0.95 & 0.79 \\
\hline Nitrate N (mg/kg) & 0.19 & 0.16 \\
\hline
\end{tabular}

$\mathrm{P}=$ Phosphorus, $\mathrm{N}=$ Nitrogen

Table 2: Mean monthly rainfall, minimum and maximum temperature during 2015-2016 and 2016-2017 seasons

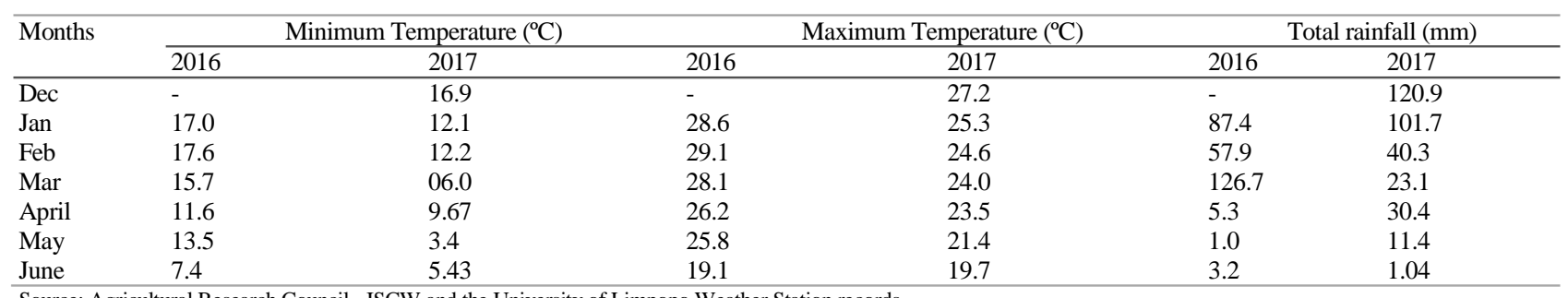

Source: Agricultural Research Council - ISCW and the University of Limpopo Weather Station records

\section{Plant harvesting}

At maturity, the number of pods per plant was determined by counting fully developed pods from the five tagged plants and the average was derived. The crops were harvested in June of each year. For grain yield, sun-dried samples were harvested from four middle rows of each plot and threshed manually to obtain grain yield per plot using electronic weighing balance and the net yield was converted to $\mathrm{kg} \mathrm{ha}^{-1}$. In the case of maize, sun-dried cob samples were harvested from two middle rows and threshed manually to obtain grain yield per plot. This was then extrapolated to grain yield per hectare.

\section{Assessment of intercrop productivity}

To assess intercrop productivity, the Land Equivalent Ratio (LER) was calculated from the relative yield of pigeonpea and maize with their sole treatments by using the following formulae (Mead and Willey 1980):

\section{$Y S 2$}

L1 and L2 are the LERs for the individual crops (soybean)

$$
\begin{aligned}
& \mathrm{LER}=\sum_{\mathrm{l}-1}^{\mathrm{n}} \quad\left(\mathrm{Y}_{\mathrm{l}}^{\mathrm{l}} / \mathrm{Y}_{\mathrm{l}}^{\mathrm{M}}\right) \quad \text { (Strip intercropping) } \\
& \mathrm{LER}=\sum_{\mathrm{l}-1}^{\mathrm{n}} \quad\left(\mathrm{Y}_{\mathrm{l}}^{\mathrm{l}} / \mathrm{Y}_{\mathrm{i}}^{\mathrm{M}}\right) \quad \text { (Mixed intercropping) }
\end{aligned}
$$

Where, YI = yield of crop $\mathrm{i}$ in intercropping, $\mathrm{YM}=$ yield of crop $\mathrm{i}$ in single cropping, and $\mathrm{n}=$ total number of crops in the intercropping system.

\section{Economic analysis}

Benefit-cost analysis was conducted to estimate the economic feasibility of different crop mixtures in the intercropping systems. The production costs of pigeonpea and maize included the cost of field preparation, seed, sowing, fertilisers, crop protection measures, harvesting and processing. The total revenue was estimated using the prevailing average market prices for the grain yield of the pigeonpea and maize in South Africa. Total profit was calculated by subtracting total cost from the total revenue, while the benefit-cost ratio (BCR) was calculated by dividing the total revenue with total cost.

\section{Data analysis}

Data collected during the two seasons were subjected to analysis of variance using the Genstat 18 Version software to determine the effect of cropping systems and season on the varieties. The data for each year were averaged to determine comparative responses of cropping systems across the varieties in the variables measured. Means that showed significant differences were separated using Fisher's Protected LSD at the probability level of 5\%.

\section{Results}

\section{Performance of the cropping systems over the seasons}

The interactions between variety $\times$ cropping system $(\mathrm{V} \times$ CS) showed significant $(P \leq 0.05)$ differences (Table 3$)$ in 
Improving Pigeonpea-maize Productivity through Strip Intercropping/ Intl J Agric Biol, Vol 25, No 1, 2021

Table 3: Number of days to $50 \%$ flowering, $90 \%$ maturity and yield component interactions between five pigeonpea varieties and cropping systems during 2015-16 and 2016-17 seasons

\begin{tabular}{|c|c|c|c|c|c|c|}
\hline \multirow[t]{2}{*}{ Varieties } & Strip intercropping & Mono-cropping & Mixed intercropping & Strip intercropping & Mono-cropping & Mixed intercropping \\
\hline & \multicolumn{3}{|c|}{$2015-2016$} & \multicolumn{3}{|c|}{ 2016-2017 } \\
\hline \multicolumn{7}{|c|}{ Number of days taken to complete $50 \%$ flowering (days) } \\
\hline ICEAP 001284 & $106.00^{\mathrm{d}}$ & $102.00^{\mathrm{e}}$ & $114.00^{\mathrm{c}}$ & $102.67^{\mathrm{f}}$ & $105.00^{\mathrm{e}}$ & $125.33^{\mathrm{a}}$ \\
\hline ICEAP 00604 & $106.33^{\mathrm{d}}$ & $105.33^{\mathrm{d}}$ & $114.00^{\mathrm{c}}$ & $105.67^{\mathrm{e}}$ & $109.00^{\mathrm{e}}$ & $125.33^{\mathrm{a}}$ \\
\hline ICEAP 00661 & $129.67^{\mathrm{a}}$ & $129.33^{\mathrm{a}}$ & $114.00^{\mathrm{c}}$ & $112.67^{\mathrm{d}}$ & $116.00^{\mathrm{c}}$ & $125.33^{\mathrm{a}}$ \\
\hline ICEAP 01101-2 & $119.00^{\mathrm{b}}$ & $118.67^{\mathrm{b}}$ & $114.00^{\mathrm{c}}$ & $120.00^{\mathrm{a}}$ & $125.67^{\mathrm{a}}$ & $125.33^{\mathrm{a}}$ \\
\hline ICEAP 87091 & $127.00^{\mathrm{a}}$ & $129.00^{\mathrm{a}}$ & $114.00^{\mathrm{c}}$ & $111.00^{\mathrm{d}}$ & $116.33^{\mathrm{c}}$ & $125.33^{\mathrm{a}}$ \\
\hline \multicolumn{7}{|c|}{ Number of days taken to complete $90 \%$ maturity (days) } \\
\hline ICEAP 001284 & $182.7^{\mathrm{a}}$ & $167.3^{\mathrm{a}}$ & $166.5^{\mathrm{a}}$ & $182.00^{\mathrm{c}}$ & $182.00^{\mathrm{c}}$ & $187.00^{\mathrm{bc}}$ \\
\hline ICEAP 00604 & $183.7^{\mathrm{a}}$ & $189.3^{\mathrm{a}}$ & $167.2^{\mathrm{a}}$ & $194.00^{\mathrm{ab}}$ & $191.67^{\mathrm{ab}}$ & $187.00^{\mathrm{bc}}$ \\
\hline ICEAP 00661 & $191.0^{\mathrm{a}}$ & $189.7^{\mathrm{a}}$ & $168.5^{\mathrm{a}}$ & $199.00^{\mathrm{a}}$ & $197.67^{\mathrm{a}}$ & $187.00^{\mathrm{bc}}$ \\
\hline ICEAP 01101-2 & $183.7^{\mathrm{a}}$ & $193.7^{\mathrm{a}}$ & $169.2^{\mathrm{a}}$ & $188.00^{\mathrm{bc}}$ & $189.33^{\mathrm{bc}}$ & $187.00^{\mathrm{bc}}$ \\
\hline ICEAP 87091 & $191.7^{\mathrm{a}}$ & $191.7^{\mathrm{a}}$ & $167.8^{\mathrm{a}}$ & $191.33^{\mathrm{a}}$ & $192.00^{\mathrm{ab}}$ & $187.00^{\mathrm{bc}}$ \\
\hline \multicolumn{7}{|c|}{ Number of primary branches } \\
\hline ICEAP 001284 & $16.67^{\mathrm{a}}$ & $17.67^{\mathrm{a}}$ & $16.33^{\mathrm{a}}$ & $15.00^{\mathrm{a}}$ & $13.00^{\mathrm{ab}}$ & $7.33^{\mathrm{bc}}$ \\
\hline ICEAP 00604 & $16.00^{\mathrm{a}}$ & $17.33^{\mathrm{a}}$ & $16.33^{\mathrm{a}}$ & $9.67^{\mathrm{abc}}$ & $6.33^{\mathrm{c}}$ & $7.33^{\mathrm{bc}}$ \\
\hline ICEAP 00661 & $18.00^{\mathrm{a}}$ & $14.33^{\mathrm{a}}$ & $16.33^{\mathrm{a}}$ & $11.00^{\mathrm{abc}}$ & $12.33^{\mathrm{abc}}$ & $7.33^{\mathrm{bc}}$ \\
\hline ICEAP 01101-2 & $20.67^{\mathrm{a}}$ & $14.33^{\mathrm{a}}$ & $16.33^{\mathrm{a}}$ & $13.00^{\mathrm{ab}}$ & $14.00^{\mathrm{a}}$ & $7.33^{\mathrm{bc}}$ \\
\hline ICEAP 87091 & $16.67^{\mathrm{a}}$ & $16.00^{\mathrm{a}}$ & $16.33^{\mathrm{a}}$ & $9.33^{\mathrm{abc}}$ & $7.33^{\mathrm{bc}}$ & $7.33^{\mathrm{bc}}$ \\
\hline \multicolumn{7}{|c|}{ Number of pods per plant } \\
\hline ICEAP 001284 & $271.7^{\mathrm{b}}$ & $275.0^{\mathrm{c}}$ & $288^{\mathrm{f}}$ & $180^{\mathrm{a}}$ & $138^{\mathrm{ab}}$ & $77^{\mathrm{ab}}$ \\
\hline ICEAP 00604 & $253.3^{\mathrm{d}}$ & $237.7^{\mathrm{e}}$ & $288^{\mathrm{f}}$ & $156^{\mathrm{ab}}$ & $124^{\text {ab }}$ & $75^{\mathrm{ab}}$ \\
\hline ICEAP 00661 & $246.0^{\mathrm{e}}$ & $257.7^{\mathrm{d}}$ & $288^{\mathrm{f}}$ & $126^{\mathrm{ab}}$ & $141^{\text {ab }}$ & $84^{\mathrm{ab}}$ \\
\hline ICEAP 01101-2 & $300.3^{\mathrm{a}}$ & $260.3^{\mathrm{b}}$ & $288^{\mathrm{f}}$ & $136^{\mathrm{ab}}$ & $135^{\mathrm{ab}}$ & $86^{\mathrm{ab}}$ \\
\hline \multirow{2}{*}{\multicolumn{7}{|c|}{$\begin{array}{l}288 \\
\text { Pigeonpea grain yields }\left(\mathrm{kg} \mathrm{ha}^{-1}\right)\end{array}$}} \\
\hline & & & & & & \\
\hline ICEAP 001284 & $1311.1^{\mathrm{a}}$ & $1065.0^{\mathrm{b}}$ & $178.0^{f}$ & $1726^{\mathrm{a}}$ & $965^{\mathrm{ab}}$ & $145^{\mathrm{d}}$ \\
\hline ICEAP 00604 & $1161.1^{\mathrm{b}}$ & $1060.0^{\mathrm{b}}$ & $178.0^{\mathrm{f}}$ & $858^{\text {ab }}$ & $632^{\mathrm{bc}}$ & $145^{\mathrm{d}}$ \\
\hline ICEAP 00661 & $494.4^{\text {ef }}$ & $495.0^{\mathrm{ef}}$ & $178.0^{\mathrm{f}}$ & $506^{\mathrm{cd}}$ & $537^{\text {cd }}$ & $145^{\mathrm{d}}$ \\
\hline ICEAP 01101-2 & $1238.9^{\mathrm{a}}$ & $935.0^{\mathrm{bc}}$ & $178.0^{\mathrm{f}}$ & $1478^{\mathrm{ab}}$ & $1150^{\mathrm{ab}}$ & $145^{\mathrm{d}}$ \\
\hline ICEAP 87091 & $744.44^{\mathrm{dc}}$ & $625.0^{\mathrm{de}}$ & $178.0^{\mathrm{f}}$ & $600^{\text {bed }}$ & $560^{\text {cd }}$ & $145^{\mathrm{d}}$ \\
\hline \multicolumn{7}{|c|}{ Maize grain yields $\left(\mathrm{kg} \mathrm{ha}^{-1}\right)$} \\
\hline Pan 6479 & $1795^{\mathrm{a}}$ & $1684^{\mathrm{b}}$ & $1088^{\mathrm{c}}$ & $1503^{\mathrm{a}}$ & $1400^{\mathrm{b}}$ & $971^{\mathrm{c}}$ \\
\hline
\end{tabular}

most of the variables measured, except the numbers of days to $90 \%$ maturity and number of branches per plant during 2015-2016 (Table 3). During the 2015-2016 season, mixed intercropping plots flowered first, followed by monocropping, while the last to flower was strip intercropping. However, during 2016-2017, varieties in the strip intercropping plots were the earliest to flower, followed by monocropping, and mixed intercropping. Regarding the number of days to maturity, although the interaction between varieties and cropping system was not significant during 2015-2016, results showed that mixed intercropping matured first compared to the rest during both seasons (Table 3). However, number of primary branches was observed to be significantly higher during both seasons among varieties planted in the strip intercropping plots, followed by monocropping, and the lowest number was from mixed intercropping (Table 3).

The pod production results indicated that mixed intercropping produced the highest number of pods, followed by strip intercropping, and monocropping during 2015-2016 (Table 3). However, during 2016-2017, strip intercropping produced the highest number of pods and the lowest number was obtained from mixed intercropping. Nonetheless, varieties planted in strip intercropping produced a significantly higher grain yield during both seasons than monocropping, and the lowest yield was obtained from mixed intercropping (Table 3). Cropping systems showed a significant difference for maize grain yields during both seasons (Table 5). The highest grain yield was recorded under strip intercropping, followed by monocropping, and the lowest grain yield was recorded under mixed intercropping during both seasons.

Data also indicated that yield advantage due to LER in strip intercropping as compared to mixed intercropping was more than one in all crop mixtures. The LER during both seasons varied significantly from 1.58 to 2.40 under strip intercropping, while under mixed intercropping, it varied from 0.34 to 1.83 during both seasons (Table 4). However, the mean values of LER obtained for 2015-2016 and 2016-2017 were not significantly different under strip intercropping or under mixed intercropping. The mean values of LER under strip intercropping were significantly higher than that of mixed intercropping during both seasons.

Results also showed that the mean relative yield, total revenue, net profit, and BCR obtained during the two seasons were a function of yield performance of the crop mixtures in the intercrop (Table 5). Among the cropping systems, the highest net profit and BCR were obtained from strip intercropping followed by monocropping and the lowest was from mixed intercropping (Table 5). 
Asiwe and Madimabe / Intl J Agric Biol, Vol 25, No 1, 2021

Table 4: Land equivalent ratio of strip and mixed intercropping during 2015-2016 season and 2016-017 seasons

\begin{tabular}{lllll}
\hline Crop mixture & \multicolumn{2}{c}{ Strip intercropping } & \multicolumn{2}{c}{ Mixed intercropping } \\
\cline { 2 - 5 } & LER 2015-2016 & LER 2016-2017 & LER 2015-2016 & LER 2016-2017 \\
\hline ICEAP 001284 + Pan 6479 & $2.40 \mathrm{a}$ & $2.31 \mathrm{a}$ & $1.83^{\mathrm{NS}}$ & $0.22^{\mathrm{NS}}$ \\
ICEAP 00604+ Pan 6479 & $2.31 \mathrm{a}$ & $2.40 \mathrm{a}$ & 0.34 & 0.34 \\
ICEAP 00661+ Pan 6479 & $1.96 \mathrm{~b}$ & $2.03 \mathrm{~b}$ & 0.44 & 0.54 \\
ICEAP 01101-2+ Pan 6479 & $1.58 \mathrm{c}$ & $1.98 \mathrm{~b}$ & 1.65 & 0.12 \\
ICEAP 87091+ Pan 6479 & $2.09 \mathrm{~b}$ & $2.04 \mathrm{~b}$ & 0.56 & 0.21 \\
\hline
\end{tabular}

Means in a column with same letters are not significantly different from each other at $P<0.05$

NS $=$ Non-significant

Table 5: Economic analysis of pigeonpea-maize strip intercropping (average of both seasons)

\begin{tabular}{|c|c|c|c|c|c|c|c|c|}
\hline Crop mixture & $\begin{array}{l}\text { Pigeonpea relative } \\
\text { yield }\left(\mathrm{kg} \mathrm{ha}^{-1}\right)\end{array}$ & $\begin{array}{l}\text { Pigeonpea } \\
\text { revenue (ZAR) }\end{array}$ & $\begin{array}{l}\text { Maize relative } \\
\text { yield }\left(\mathrm{kg} \mathrm{ha}^{-1}\right)\end{array}$ & $\begin{array}{l}\text { Maize revenue } \\
\left(\mathrm{ZAR} \mathrm{ha} \mathrm{ha}^{-1}\right)\end{array}$ & $\begin{array}{l}\text { Total revenue } \\
\left(\mathrm{ZAR} \mathrm{ha}^{-1}\right)\end{array}$ & $\begin{array}{l}\text { Total cost } \\
\left(\text { ZAR ha }^{-1}\right)\end{array}$ & $\begin{array}{l}\text { Total profit } \\
\left(\mathrm{ZAR} \mathrm{ha}^{-1}\right)\end{array}$ & BCR \\
\hline ICEAP 001284 + PAN 6479 & 1890.6 & 37812.0 & 1628.1 & 12210.4 & 50022.4 & 16547.5 & 33474.9 & 2.0 \\
\hline ICEAP 00604 + PAN 6479 & 1118.1 & 22361.0 & 799.1 & 5992.9 & 28353.9 & 10882.0 & 17471.9 & 1.6 \\
\hline ICEAP 01101-2 + Pan 6479 & 1913.9 & 38278.0 & 1072.3 & 8041.9 & 46319.9 & 15577.0 & 30742.9 & 2.0 \\
\hline ICEAP 87091 + PAN 6479 & 672.2 & 13444.0 & 852.3 & 6392.3 & 19836.3 & 9404.0 & 10432.3 & 1.1 \\
\hline Monocropping & 985.0 & 19700.0 & 1149.2 & 8618.7 & 28318.7 & 11059.0 & 17259.7 & 1.6 \\
\hline Mixed intercropping & 638.0 & 12760.0 & 555.0 & 4162.5 & 16922.5 & 10097.0 & 6825.5 & 0.6 \\
\hline
\end{tabular}

$\mathrm{BCR}=$ Benefit cost ratio; ZAR=South African Rand; 1 US $\$=16.63 \mathrm{ZAR}$

\section{Discussion}

This study has demonstrated that strip intercropping of pigeonpea and maize in a pigeonpea-maize cropping system had high potential in Limpopo Province of South Africa. Significant interaction in the number of days to $50 \%$ flowering and $90 \%$ physiological maturity of pigeonpea varieties suggested that the varieties were differently influenced by the cropping systems which could be due to varietal characteristics in their determinacy. Similar outcomes were observed by Thanga et al. (2019) who reported that significant differences among pigeonpea varieties were due to varietal characteristics. The implication is that it affords the farmers the opportunity to select early maturing varieties such as ICEAP 001284 and ICEAP 00604, which matured early during both seasons. One of the ways for crops to evade ecological stresses such as drought or frost is early maturity. In this study, we found that the two varieties that matured early under strip intercropping have the capability of completing their growth and development cycles within the rainfall duration and could evade terminal drought or early frost during winter (Leon et al. 2016). The longer period to attain $90 \%$ physiological maturity during 2016-2017 was probably the result of precipitations that occurred in April, 2017, which must have triggered a new flush of flowers and pods that created asynchrony in the maturity of the pods. This asynchrony is an important phenomenon that can be exploited by farmers to sustain their food security and reduce the need for labour in since they can harvest the crops in piece meal as they mature (Ndiritu et al. 2014; Bedoussac et al. 2015; Kermah et al. 2017). The early maturity of the varieties under the strip intercropping and monocropping suggest that the varieties were more adapted to strip intercropping and monocropping than the mixed intercropping.
Primary branches are articulation points for secondary branches where pod and peduncles are borne. In this study, significant interactions obtained between the varieties and cropping systems for the yield components (number of primary branches, number of pods per plant and grain yield) were good indications of their genetic variabilities as influenced by the cropping systems. Yield components are genetic traits of a number of grain legume crops (soybean, dry bean, cowpea, and pigeonpea) and were influenced by intercropping due to inter-plant competition between the intercrops for essential components of plant growth such as soil, water, nutrients, and sunlight (Farooq et al. 2011). Strip intercropping produced more primary branches, which in turn provided articulations to bear more pods that led to the production of higher grain yield than mixed intercropping or monocropping during both seasons. This also suggests that the varieties were more adapted to the micro-environment under strip intercropping to efficiently utilise the growth factors such as light, water, nutrients and space to produce more branches, pods, and a higher grain yield than the mixed intercropping. Similar significant variations in pigeonpea varieties for different yieldattributes were reported in previous studies (Cheboi et al. 2016; Hardev 2016; Sujatha and Babalad 2018; Thanga et al. 2019). In this study, three varieties (ICEAP 01101-2, ICEAP 00604, and ICEAP 001284) produced a higher number of primary branches, pods per plant, and higher grain yields during both seasons. The variations in yield components exhibited by the varieties during the two seasons also indicate that the season's weather conditions were different and consequently, had a significant influence on the performance of the varieties for yield components. More branches, pods and grain were produced during the 2015-2016 cropping season because rainfall and temperature distribution during the reproductive phase of 
the crops favoured the production of these yield components compared to the 2016-2017 season. This implies that these varieties were adapted to the region, and promising to be recommended for registration and release for farmers' cultivation in the Mankweng area. Previous reports have shown that significant differences in grain yields among pigeonpea varieties were due to environmental variability and genetic factor (Dasbak and Asiegbu 2009; Zerihun et al. 2016). Higher maize grain yields were recorded under monocropping than under strip intercropping (Ndiso et al. 2017). This could be due to the fact that the maize variety was developed and selected for monocropping systems and not for intercropping. The highest grain yield was recorded during 2015-2016 when weather conditions were more favourable during the critical reproductive phase (tasselling and grain-filling stages). This result agrees with previous findings of Teshome et al. (2015) who observed that sole cropped maize had significantly higher grain yield $\left(7.33 \mathrm{t} \mathrm{ha}^{-1}\right)$ than grown in an intercropped system (7.01 $\left.\mathrm{t} \mathrm{ha}^{-1}\right)$.

One of the important variables to measure the productivity of an intercropping system is the LER. Hamd et al. (2014) reported that LER of intercrop greater than 1.0 suggests that the intercropping is more efficient and productive in land utilisation when compared to mixed intercropping. The superior performance of strip intercropping over mixed intercropping in the LER could be associated with the carryover effects, and the overwhelming performance of the strip intercropping plots in the yield components obtained in this study. Dahmardeh (2013) reports that high LER values associated with strip intercropping were attributed to the morphological differences of the two crops, and efficient utilisation of resources. Intercropping cereals with grain legumes has often recorded an overall system advantage compared with sole cropping of each crop (Zhang et al. 2015). The prospect of any cropping system for adoption depends on its profitability and intercropping has been reported to give greater combined yields and monetary returns than their corresponding sole crops (Imran et al. 2011; Khan et al. 2012; Sujatha and Babalad 2018). In terms of measuring the productivity of intercropping by cash returns or profit, it is clear from the results of this study that the highest net profits and BCR were obtained from the crop mixtures of ICEAP 001284, ICEAP 00604, and ICEAP 01101-2 during the two seasons, and the lowest was obtained from ICEAP 00661 and ICEAP 87091. This is an indication that farmers will achieve a higher profit if they grow the three crop mixtures. Among the cropping systems, the highest profit was achieved from strip intercropping mixtures, followed by monocropping and the lowest was derived from mixed intercropping. This suggests that strip intercropping was consistently superior and more efficient in land and resource utilisation than the traditional mixed intercropping system to produce a higher yield and attracted a higher profit.

\section{Conclusion}

Strip intercropping out-performed mixed intercropping in terms of grain yield, LER, net profit and BCR. It should therefore, be promoted in the Mankweng region of Limpopo Province. The study also found that three varieties (ICEAP 001284, ICEAP 00604 and ICEAP 01101-2) in the crop mixtures performed very well in the cropping system and seasons and should be recommended for adoption among farmer practising strip intercropping.

\section{Acknowledgements}

The first author acknowledges the financial grant received from the Water Research Commission, South Africa (Project number K5/2494) and the support from the University of Limpopo. The authors are grateful to ICRISAT-Kenya for the supply of pigeonpea varieties used in this study.

\section{Author Contributions}

Both authors jointly contributed meticulously in the execution of the study trials in the planting, data collection, data analysis and preparation of the manuscript. The first author handled the corrections during the article review process.

\section{References}

Asiwe JAN, AK Belane, FD Dakora (2011). Assessment of $\mathrm{N}_{2}$ fixation in 32 cowpeas (Vigna unguiculata (L.). Walp) genotypes grown in the field at Taung in South Africa, using 15N natural abundance. Afr J Biotechnol 10:11450-11458

Ayenan MAT, K Ofori, TE Ahoton, A Danquah (2017). Pigeonpea [(Cajanus cajan (L.) Millsp.)] production system, farmers' preferred traits and implications for variety development and introduction in Benin. J Agric Food Sec 6; Article 48

Bedoussac L, EP Journet, H Hauggaard-Nielsen, C Naudin, G CorreHellou, ES Jensen, L Prieur, E Justes (2015). Ecological principles underlying the increase of productivity achieved by cereal-grain legume intercrops in organic farming: A review. Agron Sustain Dev 35:911-935

Carranca C, MO Torres, M Madeira (2015). Underestimated role of legume roots for soil N fertility. Agron Sustain Dev 35:1095-1102

Cheboi JJ, PK Kimurto, MG Kinyua, OK Kiplagat, BK Towett, JJ Kiptoo, SC Kirui, S Kimno, NVPG Rao (2016). Evaluation of selected pigeonpea (Cajanus cajan (L.) Millsp.) genotypes for resistance to insect pest complex in dry areas of North Rift Valley, Kenya. Amer J Exp Agric 10:1-9

Dahmardeh M (2013). Intercropping two varieties of maize and peanut: Biomass yield and intercropping advantages. Intl $J$ Agric For 3:7-11

Dasbak MAD, JE Asiegbu (2009). Performance of pigeonpea genotypes intercropped with maize under humid tropical ultisol conditions. $J$ Anim Plant Sci 4:329-340

Farooq M, K Jabran, ZA Cheema, A Wahid, KHM Siddique (2011). The role of allelopathy in agricultural pest management. Pest Manage Sci 67:493-506

Fossou RK, D Ziegler, A Zézé, F Barja, X Perret (2016). Two major clades of bradyrhizobia dominate symbiotic interactions with pigeonpea in fields of Côte d'Ivoire. Front Microbiol 7:1793-1803 
Gwata ET (2010). Potential impact of edible tropical legumes on crop productivity in the small-holder sector in Sub-Saharan Africa. J Food Agric Environ 8:939-944

Gwata ET, H Shimelis (2013). Evaluation of pigeonpea germplasm for important agronomic traits in Southern Africa. J Crop Prod 9:1-16

Hamd A, WA, EM Shalaby, RA Dawood, AA Zohry (2014). Effect of cowpea (Vigna sinensis L.) with maize (Zea mays L.) intercropping on yield and its components. Intl J Biol Bimol Agric Food Biotechnol Eng 8:1258-1264

Hardev C (2016). Performance of farmers' pigeonpea (Cajanus cajan (L.) Millsp) varieties opportunities for sustained productivity and dissemination of varieties. Intl J Agric Sci 8:3471-3474

Imran M, A Ali, M Waseem, M Tahir, AU Mohsin, M Shehzad, A Ghaffari, H Rehman (2011). Bio-economic assessment of sunflower mungbean intercropping system at different planting geometry. Intl Res J Agric Sci Soil Sci 1:126-136

Kermah M, AC Franke, S Adjei-Nsiah, BDK Ahiabor, RC Abaidoo, KE Giller (2017). Maize-grain legume intercropping for enhanced resource use efficiency and crop productivity in the Guinea savanna of northern Ghana. Field Crops Res 213:38-50

Khan M, M Hussain, M Farooq, K Jabran, DJ Lee (2012). Bio-economic assessment of different wheat-canola intercropping systems. Intl J Agric Biol 14:769-774

Kiwia A, D Kimani R Harawa, B Jama, GW Sileshi (2019). Sustainable intensification with cereal-legume intercropping in eastern and Southern Africa. Sustainability 11:2891-2908

Kutu F, JAN Asiwe (2010). Assessment of maize and dry bean productivity under different intercrop systems and fertilization regimes. Afr $J$ Agric Res 5:1627-1631

Leon N, J Jean-Luc, WE Jode, MK Shawn (2016). Introduction to a special issue on genotype by environment interaction. Crop Sci 56:20812089

Loboguerrero AM, BM Campbell, PJM Cooper, JW Hansen, T Rosenstock, E Wollenberg (2019). Food and earth systems: Priorities for climate change adaptation and mitigation for agriculture and food systems. Sustainability 11; Article 1372

Mango N, L Mapemba, H Tchale, C Makate, N Dunjana, M Lundy (2018). Maize value chain analysis: A case of smallholder maize production and marketing in selected areas of Malawi and Mozambique. Cogent Busin Manage 5; Article 1503220

Mathews C, R Jones, K Saxena (2001). Maize and pigeonpea intercropping systems in Mpumalanga, South Africa. Intl Chickpea Pigeonpea Newslett 8:52-53

Mead R, RW Willey (1980). The concept of a land equivalent ratio and advantages in yields for intercropping. Exp Agric 16:217-222
Nassary EK, F Baijukya, PA Ndakidemi (2020). Sustainable intensification of grain legumes optimizes food security on smallholder farms in Sub-Saharan Africa-A Review. Intl J Agric Biol 23:25-41

Ndiritu SW, M Kassie, B Shiferaw (2014). Are there systematic gender differences in the adoption of sustainable agricultural intensification practices? Evidence from Kenya. Food Policy 49:117-127

Ndiso JB, GN Cheminingwa, FM Olubayo, HM Saha (2017). Effect of cropping system on soil moisture content, canopy temperature, growth and yield performance of maize and cowpea. Intl J Agric Sci 7:1271-1281

Njira K, PC Nalivata, GY Kanyama-Phiri, MW Lowole (2012). Biological nitrogen fixation in sole and doubled-up legume cropping systems in the sandy soils of Kasungu, Central Malawi. J Soil Sci Manage 3:224-230

Saxena K, R Kumar, P Rao (2002). Pigeonpea nutrition and its improvement. J Crop Prod 5:227-260

Shah TR, K Prasad, P Kumar (2016). Maize-A potential source of human nutrition and health: A review. Cogent Food Agric 2; Article 1166995

Sharma A, PS Rathod, M Chavan, PS Dharmaraj (2010). Crop residue management in pigeonpea-based intercropping systems under rainfed conditions. Ind J Dryland Agric Res Dev 25:47-52

Singh B, H Ajeigbe (2007). Improved cowpea-cereals-based cropping systems for household food security and poverty reduction in West Africa. J Crop Improv 19:157-172

Richandan S, AK Mangaraj (2015). Growth, yield and yield attributes of pigeonpea in rainfed uplands of western central table land zone of Odisha. Intl J Agric For 2:10-13

Sujatha HT, HB Babalad (2018). System productivity and economics of transplanted and direct sown pigeonpea at different cropping geometry and intercropping systems. Intl J Pure Appl Biosci 6:694700

Teshome G, T Tamado, G Negash (2015). Effect of varieties and population of intercropped soybean with maize on yield and yield components at Haro Sabu, Western Ethiopia. Sci Technol Arts Res J 4:31-39

Thanga A, JR Hemavathy, B Kannan, M Priyadharshini (2019). Genetic variability and character association in pigeonpea [Cajanus cajan (L.) Millsp.] core collection. Ind J Agric Res 53:362-365

Zerihun A, T Shiferaw, T Meseret (2016). Multiple advantages of pigeonpea (Cajanus cajan (L.) Millsp.) in maize based cropping systems: Used as live stakes for climbing bean with phosphorus rates and maize productivity enhancement in monocropping. J Nat Sci Res $6: 8-18$

Zhang Y, J Liu, J Zhang, H Liu, S Liu, L Zhai, H Wang, Q Lei, T Ren, C Yin (2015). Row ratios of intercropping maize and soybean can affect agronomic efficiency of the system and subsequent wheat. PLoS One 6; e0129245 